\title{
Polysaccharide from Anacardium occidentale L. tree gum (Policaju) as a coating for Tommy Atkins mangoes
}

\author{
${ }^{a}$ Marthyna P. Souza, ${ }^{b}$ Miguel A. Cerqueira, b Bartolomeu W. S. Souza, \\ bosé A. Teixeira, ${ }^{\mathrm{c}, \mathrm{d}}$ Ana L. F. Porto, ${ }^{\mathrm{b}}$ António A. Vicente, \\ ${ }^{\mathrm{a}, \mathrm{c}}$ Maria G. Carneiro-da-Cunha* \\ a Departamento de Bioquímica, Universidade Federal de Pernambuco, \\ Av. Prof Moraes Rego, s/n, Cidade Universitária, 50670-420 Recife, PE - Brazil \\ ${ }^{\mathrm{b}} I B B$ - Institute for Biotechnology and Bioengineering, Centre of Biological Engineering, Universidade do Minho, \\ Campus de Gualtar, 4710-057 Braga, Portugal \\ ${ }^{\mathrm{c}}$ Laboratório de Imunopatologia Keizo Asami, Universidade Federal de Pernambuco, Campus Universitário, s/n, \\ Cidade Universitária, 50670-901 Recife, PE - Brazil \\ d Departamento de Morfologia e Fisiologia Animal, Universidade Federal Rural de Pernambuco-UFRPE, \\ Av. Dom Manoel de Medeiros, s/n, 52171-900 Recife, PE - Brazil
}

Received 30 September 2009; Revised 17 November 2009; Accepted 19 November 2009

\begin{abstract}
Policaju-based coatings were applied on "Tommy Atkins" mangoes and the effects of four different treatments on mango shelf-life were evaluated under storage condition at $4{ }^{\circ} \mathrm{C}$ and $82 \%$ of relative humidity over 28 days. The surface tension of mangoes was found to be $29.04 \mathrm{mN} \mathrm{m}^{-1}$; the dispersive and polar components were $27.57 \mathrm{mN} \mathrm{m}^{-1}$ and $1.47 \mathrm{mN} \mathrm{m}^{-1}$, respectively, and the critical surface tension was $22.7 \mathrm{mN} \mathrm{m}^{-1}$. A significantly lower mass loss was observed in all mangoes treated with Policaju-based coatings. For all applied treatments, no significant variation in the total soluble solids and $\mathrm{pH}$ was detected over the experimental storage time. The results show that Policaju-based coatings have a positive effect on the shelf-life extension of mangoes at low storage temperatures $\left(4^{\circ} \mathrm{C}\right)$.

(C) 2010 Institute of Chemistry, Slovak Academy of Sciences
\end{abstract}

Keywords: Policaju, edible coating, shelf-life, mango

\section{Introduction}

Increase of the demand for fresh fruits and vegetables, great losses of quality occurring from the harvesting to the final consumption, and short shelf-life of fruits force the food industry to develop new and better methods of food quality preservation and to extend the shelf-life as well. Besides, all over the world, consumers demand high quality food without chemical preservatives and with extended shelf-life. These factors, taken together, raise the demand for new natural preservatives and antimicrobials (Chien et al.,
2007; Lin \& Zhao, 2007). Implementation of optimum storage conditions through refrigeration and modified atmosphere or combination of both can be quite effective in maximizing shelf-life and quality of food products. This requires the control of factors such as temperature, relative humidity, gas composition, light, and mechanical/physical stress. However, there is a need for new methods that can be easily applied to smaller amounts of the product at a lower price, while maintaining the preservation efficiency. Edible coatings creating a modified atmosphere surrounding the commodity, with a similar effect to that achieved by

*Corresponding author, e-mail: mgcc@ufpe.br 
controlled or modified atmospheric storage conditions, have been considered. Modified atmosphere created by edible coatings protects the food from the moment it is applied until it reaches the final consumer ( $\mathrm{Du}-$ rango et al., 2006; Ribeiro et al., 2007). Several researchers have studied the application of coatings on fruits such as apple (Rojas-Graü et al., 2007), strawberries (Ribeiro et al., 2007), mango (Chien et al., 2007; Dang et al., 2008), fresh-cut melon (Oms-Oliu et al., 2008), tomato (Casariego et al., 2008), avocados (Maftoonazad \& Ramaswamy, 2005), and litchi fruit (Jiang et al., 2005). Polysaccharide-based coatings are colorless with an oil-free appearance and low caloric content and can be used to increase the shelf-life of fruits, vegetables, shellfish or meat products avoiding or significantly reducing dehydration, oxidative rancidity, and darkening of the surface. Other characteristics that make them attractive are their transport properties, permeability to $\mathrm{CO}_{2}, \mathrm{O}_{2}$, and water vapor, reducing e.g. the mass loss and the microbial spoilage of fruits (Dang et al., 2008). The knowledge of the wettability of coatings is also of particular importance as it is a parameter that defines the ability of a coating to be uniformly distributed on the surface of the fruit (Lin \& Zhao, 2007) thus directly affecting its performance as a preservation agent.

Mango is a seasonal fruit that ripens quickly after harvest (between 3 days and 9 days) and, consequently, presents serious restrictions to long distance marketing (Gomez-Lim, 1997). Sensitivity to disease and low temperature as well as the deterioration due to ripening or softening of the fruit, limit its potential in terms of storage, packaging, and transport (Mitra \& Baldwin, 1997). However, Shivashankara et al. (2004) showed that lower storage temperatures can be used with Irwin mangoes to improve their shelf-life.

The polyssaccaride obtained from cashew gum (Policaju) is a complex polysaccharide formed by galactose $(73.0 \%)$, glucose $(11.0 \%)$, arabinose $(5.0 \%)$, rhamnose $(4.0 \%)$, mannose $(1.0 \%)$, and glucuronic acid $(6.3 \%)$ with a highly branched galactan framework consisting of chains of $(1 \rightarrow 3)$-linked $\beta$-D-galactopyranosyl units with interspersed $\beta(1 \rightarrow 6)$ linkages (Paula \& Rodrigues, 1995). This nontoxic, hydrophilic, biocompatible, and biodegradable polysaccharide presenting interesting biological activities such as anti-inflammatory and wound healing, has been reported as a potential constituent agent of films (Carneiro-da-Cunha et al., 2009) and suggested as a support for the immobilization of biomolecules (Schirato et al., 2006; Monteiro et al., 2007).

This polysaccharide is a cheap alternative to existing (mostly synthetic) substances and has the advantage of being produced locally, near the harvesting sites of mango. The development of these applications from natural products and its use in the production sites to increase the fruit shelf-life can be an important contribution to the economy of countries like Brazil.
In this work, coatings based on the polysaccharide from Anacardium occidentale L. tree gum (Policaju) were evaluated as edible coatings extending the shelflife of mangoes, at a low storage temperature of $4^{\circ} \mathrm{C}$, following closely the chemical changes of mangoes over 28 days of storage. Prior to the application of different coatings, the mangoes surface properties were evaluated and the coating composition was optimized in terms of its wettability.

\section{Experimental}

"Tommy Atkins" mangoes were purchased from a local producer (Pernambuco, Brazil). Sorbitol $97 \%$ and Tween 80 were obtained from Acros Organics, Belgium. Polysaccharide from A. occidentale L. tree gum (collected from cashew in the South coast of Pernambuco, Brazil) was obtained according to the modified method of Menestrina et al. (1998) and termed Policaju. Briefly, cashew gum (20 g) was crushed and dissolved in distilled water $(100 \mathrm{~mL})$ under magnetic stirring $\left(200 \mathrm{~min}^{-1}\right)$ for $2-3 \mathrm{~h}$ at room temperature $\left(25^{\circ} \mathrm{C}\right)$. The solution was filtered through a Vual tissue followed by a new filtration using screen printing cloth (90 thread type), and precipitated with ethanol (1:3). The precipitate (Policaju) was dissolved in distilled water, filtered using screen printing cloth (110 thread type) and finally dried at $30^{\circ} \mathrm{C}$ to remove residual ethanol.

\section{Properties of mangoes}

As uniform as possible, the mangoes were selected according to the same semi-mature state (color and smell) with similar size, absence of damage and fungal infection and then washed with distilled water. Thin portions of the outer surface (skin) of mangoes were cut with a knife and placed on a glass plate for contact angle measurement.

According to Zisman (1964), in systems with a surface tension lower than $100 \mathrm{mN} \mathrm{m}^{-1}$ (low-energy surfaces), the contact angle formed by a liquid drop on a solid surface will be a linear function of the surface tension of the liquid, $\gamma_{\mathrm{LV}}$, (where phase $\mathrm{V}$ is air saturated with the vapor of liquid $\mathrm{L}$ ). The Zisman method is applicable only for low energy surfaces; therefore it is necessary to determine the surface energy of mangoes.

For a pure liquid, if polar $\left(\gamma_{\mathrm{L}}^{\mathrm{p}}\right)$ and dispersive $\left(\gamma_{\mathrm{L}}^{\mathrm{d}}\right)$ interactions are known, and if $\theta$ is the contact angle between that liquid and a solid, the interaction can be described in terms of the reversible work of adhesion, $W_{\mathrm{a}}$, as

$$
W_{\mathrm{a}}=W_{\mathrm{a}}^{\mathrm{d}}+W_{\mathrm{a}}^{\mathrm{p}} \Leftrightarrow W_{\mathrm{a}}=2\left(\sqrt{\gamma_{\mathrm{S}}^{\mathrm{d}} \gamma_{\mathrm{L}}^{\mathrm{d}}}+\sqrt{\gamma_{\mathrm{S}}^{\mathrm{p}} \gamma_{\mathrm{L}}^{\mathrm{p}}}\right)
$$

where $\gamma_{\mathrm{S}}^{\mathrm{p}}$ and $\gamma_{\mathrm{S}}^{\mathrm{d}}$ are the polar and dispersive contributions of the surface of the studied solid. Rearranging 
Eq. (1), the following equation is obtained

$$
\frac{1+\cos \theta}{2} \frac{\gamma_{\mathrm{L}}}{\sqrt{\gamma_{\mathrm{L}}^{\mathrm{d}}}}=\sqrt{\gamma_{\mathrm{S}}^{\mathrm{p}}} \sqrt{\frac{\gamma_{\mathrm{L}}^{\mathrm{p}}}{\gamma_{\mathrm{L}}^{\mathrm{d}}}}+\sqrt{\gamma_{\mathrm{S}}^{\mathrm{d}}}
$$

Contact angle determinations of at least three pure compounds: bromonaphthalene (Merck, Germany), formamide (Merck, Germany), and ultra pure water, on the surface of mangoes (fruit skin) combined with the dispersive and polar component values allow calculating both the independent $\left(\sqrt{\frac{\gamma_{\mathrm{L}}^{\mathrm{p}}}{\gamma_{\mathrm{L}}^{\mathrm{d}}}}\right)$ and the dependent $\left(\frac{1+\cos \theta}{2} \frac{\gamma_{\mathrm{L}}}{\sqrt{\gamma_{\mathrm{L}}^{\mathrm{d}}}}\right)$ variables in Eq. (2).

Surface tension, the dispersive and the polar component were, respectively, $72.10 \mathrm{mN} \mathrm{m}^{-1}, 19.90$ $\mathrm{mN} \mathrm{m}{ }^{-1}$, and $52.20 \mathrm{mN} \mathrm{m}^{-1}$ for water, $44.40 \mathrm{mN}$ $\mathrm{m}^{-1}, 44.40 \mathrm{mN} \mathrm{m}^{-1}$, and $0.00 \mathrm{mN} \mathrm{m}^{-1}$ for bromonaphtalene, and $56.90 \mathrm{mN} \mathrm{m}^{-1}, 23.50 \mathrm{mN} \mathrm{m}^{-1}$, and $33.40 \mathrm{mN} \mathrm{m}^{-1}$ for formamide (Busscher et al., 1984).

Estimation of the critical surface tension $\left(\gamma_{C}\right)$ was performed by extrapolation from Zisman plots (Zisman, 1964). These plots allow calculating the critical surface tension $\left(\gamma_{\mathrm{C}}\right)$ defined as

$$
\gamma_{\mathrm{C}}=\lim \gamma_{\mathrm{LV}} \quad \text { as } \quad \theta \rightarrow 0^{\circ}
$$

Wettability was studied determining the values of the spreading coefficient $\left(W_{\mathrm{s}}\right)$ and the works of adhesion $\left(W_{\mathrm{a}}\right)$ and cohesion $\left(W_{\mathrm{c}}\right)$. Adhesive forces promote the liquid spreading in a solid surface and cohesive forces promote their contraction. Wetting behavior of the solutions mainly depends on the balance between these forces. Surface tension of the coating solution was measured by the pendant drop method using the Laplace-Young approximation (Song \& Springer, 1996).

The contact angle $(\theta)$ of a liquid drop on a solid surface is defined by the mechanical equilibrium of the drop under the action of three interfacial tensions: solid-vapor $\left(\gamma_{\mathrm{SV}}\right)$, solid-liquid $\left(\gamma_{\mathrm{SL}}\right)$, and liquid-vapor $\left(\gamma_{L V}\right)$. The equilibrium spreading coefficient $\left(W_{\mathrm{s}}\right)$ is defined by Eq. (4) (Rulon \& Robert, 1993 ) and its value can only be negative or zero

$$
W_{\mathrm{s}}=W_{\mathrm{a}}-W_{\mathrm{c}}=\gamma_{\mathrm{SV}}-\gamma_{\mathrm{LV}}-\gamma_{\mathrm{SL}}
$$

where the works of adhesion, $W_{\mathrm{a}}$, and cohesion, $W_{\mathrm{c}}$, are defined by Eqs. (5) and (6), respectively,

$$
\begin{gathered}
W_{\mathrm{a}}=\gamma_{\mathrm{LV}}+\gamma_{\mathrm{SV}}-\gamma_{\mathrm{SL}} \\
W_{\mathrm{c}}=2 \gamma_{\mathrm{LV}}
\end{gathered}
$$

The contact angle $(\theta)$ and the liquid-vapor surface tension $\left(\gamma_{\mathrm{LV}}\right)$ were measured in a face contact angle meter (OCA 20, Dataphysics, Germany). Samples of the coatings were taken with a $0.75 \mathrm{~mm}$ diameter 500 $\mu \mathrm{L}$ syringe (Hamilton, Switzerland). The contact angle at the mangoes' skin surface was measured by the sessile drop method (Kwok \& Neumann, 1999). Measurements were done in less than $30 \mathrm{~s}$. Ten replicates of contact angle and surface tension measurements were obtained at $(21.3 \pm 0.5)^{\circ} \mathrm{C}$. Wettability determinations were performed with Policaju concentrations of $0.015 \mathrm{~g} \mathrm{~mL}^{-1}$ and $0.03 \mathrm{~g} \mathrm{~mL}^{-1}$. Tween 80 was used as surfactant to improve the wettability of the solution on the mangoes' surface, five different concentrations were used $\left(0.25 \times 10^{-3} \mathrm{~g} \mathrm{~mL}^{-1}, 0.5 \times 10^{-3} \mathrm{~g} \mathrm{~mL}^{-1}\right.$, $0.75 \times 10^{-3} \mathrm{~g} \mathrm{~mL}^{-1}, 1.0 \times 10^{-3} \mathrm{~g} \mathrm{~mL}^{-1}$, and 2.0 $\left.\times 10^{-3} \mathrm{~g} \mathrm{~mL}^{-1}\right)$. All coatings contained sorbitol as a plasticizer at the concentration of $0.004 \mathrm{~g} \mathrm{~g}^{-1}$.

\section{Mangoes treatment and shelf-life analysis}

Coating solutions were prepared by dissolving $0.015 \mathrm{~g} \mathrm{~mL}^{-1}$ or $0.03 \mathrm{~g} \mathrm{~mL}^{-1}$ Policaju in distilled water under agitation using a magnetic stirrer for $24 \mathrm{~h}$ at room temperature $\left(25^{\circ} \mathrm{C}\right)$. Subsequently, sorbitol as a plasticizer and Tween 80 were added to the Policaju solution in concentrations of $0.004 \mathrm{~g} \mathrm{~g}^{-1}$ and between $0-2 \times 10^{-3} \mathrm{~g} \mathrm{~mL}^{-1}$, respectively.

Washed mangoes were dipped into a 0.5 vol. \% sodium hypochlorite solution for $3 \mathrm{~min}$, washed twice with distilled water and left to dry. After drying, they were kept at room temperature $\left(25^{\circ} \mathrm{C}\right.$, close to the temperature of the wettability tests) and at the relative humidity $(\mathrm{RH})$ of $66.6 \%$ until coating application.

Mangoes were arranged into five groups according to the applied coatings: $0.015 \mathrm{~g} \mathrm{~mL}^{-1}$ of Policaju (P1.5\%), $0.03 \mathrm{~g} \mathrm{~mL}^{-1}$ of Policaju (P3.0\%), $0.015 \mathrm{~g}$ $\mathrm{mL}^{-1}$ of Policaju with Tween 80 (P1.5\%tw), $0.03 \mathrm{~g}$ $\mathrm{mL}^{-1}$ of Policaju with Tween 80 (P3.0\%tw), and the control group without coating. All coatings contained sorbitol as a plasticizer at the concentration of 0.004 $\mathrm{g} \mathrm{g}^{-1}$. Each group was dipped into the corresponding treatment solution for $2 \mathrm{~min}$, the residual coating being allowed to drip off.

The mangoes were randomly divided into five groups of twelve mangoes each and they were stored at $4^{\circ} \mathrm{C}$ and $82 \% \mathrm{RH}$ for 28 days. On the 1st, 7th, 15th, and 28th day of storage, three mango samples were peeled off and cut lengthwise to remove the stones. The juice samples were squeezed from the two slices of each mango and collected in sterilized jars in aseptic conditions. Afterwards, the juice was centrifuged at $402 \mathrm{~g}$ for $5 \mathrm{~min}$ and the flesh total soluble solids (TSS) were determined on the supernatant using a refractometer (Atago Automatic - Master T, Japan). For $\mathrm{pH}$ determination, mango flesh was triturated and gauged with a potentiometer (Analyses pH 300 M, Brazil).

The mass loss was evaluated with a semi-precision balance (B-TEC-500, Brazil); all mangoes were indi- 
vidually weighed at the beginning of the study and during the storage time. The mass loss was expressed as

$$
W_{\mathrm{a}}=\Delta W=\frac{m_{\mathrm{i}}-m_{t}}{m_{\mathrm{i}}} 100 \%
$$

where $m_{\mathrm{i}}$ is the initial mass and $m_{t}$ is the mass at time $t$. Each physico-chemical analysis was performed in three replicates.

All data for the variables were analyzed and compared using ANOVA (for $W_{\mathrm{a}}, W_{\mathrm{c}}, W_{\mathrm{s}}$, mass loss, TSS) and the Tukey test $(p=0.05)$ (for $\mathrm{pH}$ ) (SigmaStat, trial version, USA) to determine the significance of differences found between the treatments (corresponding to the five groups described here). Regression analysis used for determination of the surface and critical surface tension was performed using SigmaStat (USA).

\section{Results and discussion}

The mangoes' skin dispersive component $((27.57$ $\left.\pm 0.01) \mathrm{mN} \mathrm{m}^{-1}\right)$ is higher than the polar component $\left((1.47 \pm 0.01) \mathrm{mN} \mathrm{m}^{-1}\right)$, which shows the ability of this fruit's surface to participate in non-polar interactions; the surface tension of mangoes was (29.04 \pm $0.02) \mathrm{mN} \mathrm{m}^{-1}$. The obtained value of the mangoes' critical surface tension was $(22.7 \pm 0.02) \mathrm{mN} \mathrm{m}^{-1}$, allowing to conclude that the mangoes have a lowenergy surface (i.e., below $100 \mathrm{mN} \mathrm{m}^{-1}$ ) and that the Zisman method is therefore applicable. On the other hand, values of critical surface tension must be lower than those of the surface tension (Dann, 1970), which holds true for all mangoes used in this study.

The wettability of mangoes' skin was studied determining the values of the work of adhesion $\left(W_{\mathrm{a}}\right)$, work of cohesion $\left(W_{\mathrm{c}}\right)$, and the spreading coefficient $\left(W_{\mathrm{s}}\right)$. The presence of Tween 80 decreases the values of $W_{\mathrm{a}}$ and $W_{\mathrm{c}}$ (Fig. 1) and allows a better (higher) value of $W_{\mathrm{s}}$ to be achieved (Fig. 2). The addition of Tween 80 to the solution decreased the cohesion forces substantially, as expressed by $W_{\mathrm{c}}$ (Fig. 1), with a statistically significant difference $(p<0.05)$. Tween 80 reduces the surface tension of the liquid and increases $W_{\mathrm{s}}$, improving thus the compatibility of the solution and the fruit's skin surface. Other authors show the ability of Tween 80 to decrease $W_{\mathrm{c}}$ in the fruits improving the wettability of the solutions (Ribeiro et al., 2007). Fig. 2 shows that with the increase of Tween 80 concentration, the value of $W_{\mathrm{s}}$ increases as well reaching an optimal value at the Tween 80 concentration of $2.0 \times 10^{-3} \mathrm{~g} \mathrm{~mL}^{-1}$, both with Policaju concentrations of $0.015 \mathrm{~g} \mathrm{~mL}^{-1}$ and $0.03 \mathrm{~g} \mathrm{~mL}^{-1}$. Similar findings were reported by Carneiro-da-Cunha et al. (2009) using the Tween 80 concentration of $1.0 \times 10^{-3} \mathrm{~g} \mathrm{~mL}^{-1}$. In our work, a statistically significant difference $(p<$ 0.05) was also found between these Policaju concentrations and values of $W_{\mathrm{s}}$ obtained in the absence of Tween 80.

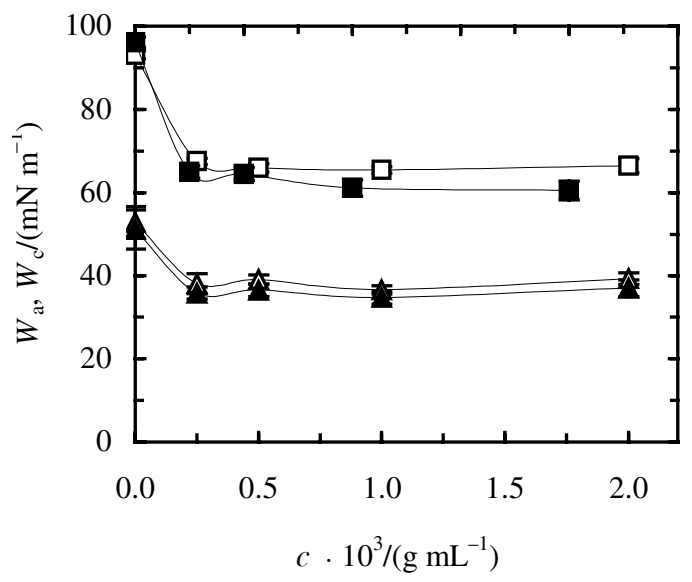

Fig. 1. Values of the work of adhesion $\left(W_{\mathrm{a}}\right)$ and work of cohesion $\left(W_{\mathrm{c}}\right)$ of Policaju-based coatings applied on mangoes; Policaju concentrations of $0.015 \mathrm{~g} \mathrm{~mL}^{-1}$ and $0.03 \mathrm{~g} \mathrm{~mL}^{-1}$ and different concentrations $(c)$ of Tween 80. Key: (ם) $W_{\mathrm{c}} \mathrm{P} 1.5 \% \mathrm{tw},(\square) W_{\mathrm{c}} \mathrm{P} 3.0 \% \mathrm{tw},(\triangle) W_{\mathrm{a}}$ $\mathrm{P} 1.5 \%$ tw and $(\boldsymbol{\Delta}) W_{\mathrm{a}} \mathrm{P} 3.0 \%$ tw. Each data point is an average of 10 experiments; error bars show standard deviation.

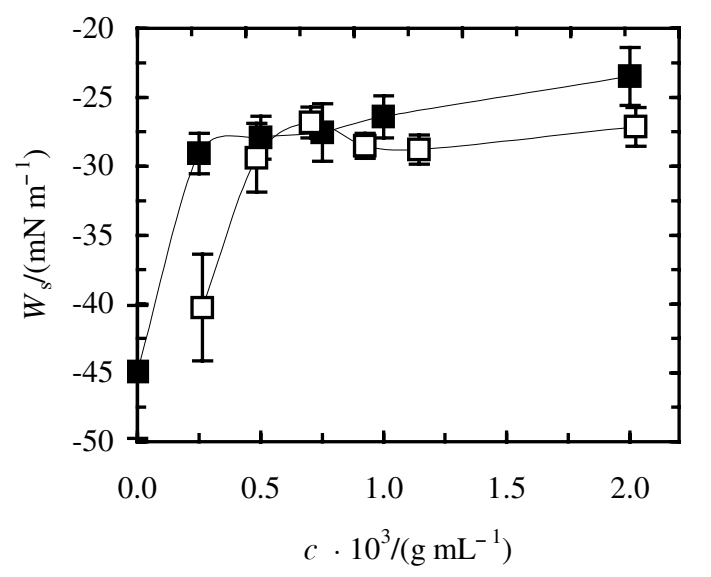

Fig. 2. Values of the spreading coefficient $\left(W_{\mathrm{s}}\right)$ of Policajubased coatings applied on mangoes; Policaju concentrations of $0.015 \mathrm{~g} \mathrm{~mL}^{-1}$ and $0.03 \mathrm{~g} \mathrm{~mL}^{-1}$ and different concentrations (c) of Tween 80. Key: (ם) Ws P1.5\%tw and (ם) Ws P3.0 \%tw. Each data point is an average of 10 experiments; error bars show standard deviation.

Four solutions were chosen for further application on mangoes' skin and for the study of the effect of Policaju coatings on mango shelf-life. The solutions were prepared with Policaju concentrations of 0.015 $\mathrm{g} \mathrm{mL}-1$ and $0.03 \mathrm{~g} \mathrm{~mL}^{-1}$, both without and with $0.5 \times 10^{-3} \mathrm{~g} \mathrm{~mL}^{-1}$ Tween 80 . This concentration of Tween 80 was selected because no statistically significant difference was observed between the values of $W_{\mathrm{s}}$ for coatings with the Policaju concentration of 0.015 $\mathrm{g} \mathrm{mL}{ }^{-1}$ containing $0.5 \times 10^{-3} \mathrm{~g} \mathrm{~mL}^{-1}$ or more of Tween 80. For coatings with the Policaju concentration of $0.03 \mathrm{~g} \mathrm{~mL}^{-1}$, the optimal value of Tween 80 concentration was found to be $2.0 \times 10^{-3} \mathrm{~g} \mathrm{~mL}^{-1}$, 


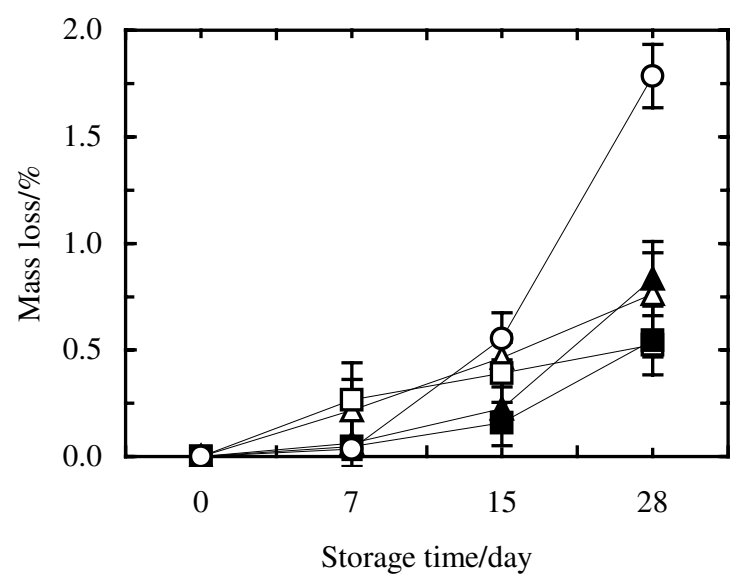

Fig. 3. Mass loss of "Tommy Atkins" mangoes treated with the following coatings: $(\mathrm{O})$ control, $(\triangle) \mathrm{P} 1.5 \%,(\boldsymbol{\Delta})$

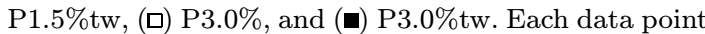
is an average of 3 experiments; error bars show standard deviation.

corresponding to the $W_{\mathrm{s}}$ value of $(-23.48 \pm 2.09) \mathrm{mN}$ $\mathrm{m}^{-1}$. Though being statistically different from the $W_{\mathrm{s}}$ value obtained for the Tween 80 concentration of 0.5 $\times 10^{-3} \mathrm{~g} \mathrm{~mL}^{-1}(-27.92 \pm 1.55) \mathrm{mN} \mathrm{m}^{-1}$, the gain in $W_{\mathrm{s}}$ does not justify a four-fold increase in the concentration of Tween 80 . Thereby, the Tween 80 concentration of $0.5 \times 10^{-3} \mathrm{~g} \mathrm{~mL}^{-1}$ was chosen for both Policaju solutions $\left(0.015 \mathrm{~g} \mathrm{~mL}^{-1}\right.$ and $\left.0.03 \mathrm{~g} \mathrm{~mL}^{-1}\right)$ thus reducing the cost of the coating. Coatings with lower values of $W_{\mathrm{s}}$ (i.e., those without Tween 80 ) were also tested on mangoes to evaluate the influence of a decrease of approximately $30 \%$ of the $W_{\mathrm{s}}$ value on the shelf-life of the coated mangoes.

\section{Physico-chemical analysis}

Change in the mass of the coated fruit has to be monitored during the storage time to determine how effective the coating is as a moisture barrier. It can be considered that mass loss corresponds almost exclusively to water loss since other components that can be lost, such as aromas or flavors, and gaseous products of respiration, are practically undetectable in terms of mass (Olivas \& Barbosa-Cánovas, 2005). Fig. 3 shows that on the 28 th day of storage there are statistically significant differences $(p<0.05)$ between the mangoes without coating (control group) and the mangoes with coating. The mangoes with coating presented lower mass loss in comparison with the control group and the difference ranged between $53.2 \%$ and $70.6 \%$. The best value in terms of mass loss reduction was obtained with the coating containing 0.03 $\mathrm{g} \mathrm{mL} \mathrm{m}^{-1}$ Policaju. These differences can be related to the water vapor permeability of the Policaju coating which decreases the water loss of the mango and, consequently, the mass loss. Similar results were obtained by Sothornvit and Rodsamran (2008), showing that a mango film applied on the whole fruit reduces its mass loss significantly. Assis and Leoni (2003) showed that the mass loss of apples was reduced by $10 \%$ when a chitosan-based coating was used. Furthermore, Ribeiro et al. (2007) presented good results using starch- and carrageenan-based coatings on strawberries and Dang et al. (2008) showed that the mass loss in mangoes covered with a carnauba-based coating was reduced compared with the control group and other coatings.

Differences between the coatings with and without Tween 80 can also be observed in Fig. 3. Coatings with Tween 80 showed a lower mass loss of coated mangoes until the 15 th day of storage. However, such difference becomes not statistically significant on the 28th day of storage. As explained by Carneiro-da-Cunha et al. (2009), it is expected that the presence of Tween 80 lowers the WVP of the films, which was observed in the present work.

It is also worthwhile to notice that from the 15 th day of storage onwards, the concentration of Policaju seems to be determinant for the observed mass loss, which is higher for $0.015 \mathrm{~g} \mathrm{~mL}^{-1}$ Policaju films than for $0.03 \mathrm{~g} \mathrm{~mL}^{-1}$ Policaju films.

Total soluble solids (TSS) are used as an indicator of total sugar content in fruits providing information about the fruit maturation state. TSS is formed by water-soluble compounds of substances like sugars, acids, vitamin $\mathrm{C}$, and some pectins (Oliveira et al., 1999). In the present work, no significant differences $(p>0.05)$ of the obtained TSS values, ranging between $11.00^{\circ}$ Brix and $12.66^{\circ}$ Brix, were observed indicating that the coating had no effect on this parameter. These values are in agreement with Brunini et al. (2002) for "Tommy Atkins" mangoes, where the TSS values were also found to be constant during the storage time for all treatments considered. Chien et al. (2007) presented similar results, without variation of TSS, when chitosan-based coatings were used to extend the shelf-life of mangoes. Also Ribeiro et al. (2007) showed that the content of solids in strawberries did not vary significantly during the storage. Sothornvit and Rodsamran (2008) found that the storage temperature was the only factor affecting the TSS in mangoes (Mangifera indica L.) during the ripening. Shivashankara et al. (2004) working with mangoes (cv. Irwin) previously exposed to high electric field treatment and then stored for 20 days and 30 days at $5{ }^{\circ} \mathrm{C}$, did not find changes in TSS and concluded that mangoes of cv. Irwin are more suitable for low temperature storage and can be successfully stored for up to 20 days at $5^{\circ} \mathrm{C}$ without any significant losses in the functional properties and quality attributes.

According to Olivas and Barbosa-Cánovas (2005), water content and water loss in the fruits during the storage should always be considered for the interpretation of soluble solids values. Water loss causes an apparent increase of the concentration of soluble solids 
Table 1. $\mathrm{pH}$ of "Tommy Atkins" mangoes depending on storage time at $4{ }^{\circ} \mathrm{C}$

\begin{tabular}{|c|c|c|c|c|c|}
\hline \multirow{2}{*}{$\begin{array}{c}\text { Storage } \\
\text { time/days }\end{array}$} & \multicolumn{5}{|c|}{$\mathrm{pH}$} \\
\hline & Control & $\mathrm{P} 1.5 \%$ & $\mathrm{P} 1.5 \%$ tw & P3.0\% & P3.0 \%tw \\
\hline 1 & $4.92 \pm 0.36^{a}$ & $5.02 \pm 0.02^{a}$ & $4.76 \pm 0.22^{a}$ & $5.06 \pm 0.15^{a}$ & $4.66 \pm 0.18^{a}$ \\
\hline 7 & $4.93 \pm 0.19^{a}$ & $5.10 \pm 0.10^{a}$ & $5.11 \pm 0.18^{a}$ & $4.89 \pm 0.25^{a}$ & $4.62 \pm 0.21^{a}$ \\
\hline 15 & $5.31 \pm 0.39^{a}$ & $5.28 \pm 0.15^{a}$ & $5.11 \pm 0.04^{a}$ & $4.99 \pm 0.41^{a}$ & $4.74 \pm 0.31^{a}$ \\
\hline 28 & $5.11 \pm 0.14^{a}$ & $5.22 \pm 0.26^{a}$ & $5.17 \pm 0.04^{a}$ & $5.04 \pm 0.02^{a}$ & $5.23 \pm 0.41^{a}$ \\
\hline
\end{tabular}

a) Equal superscript letters indicate the absence of statistically significant differences (Tukey test $p<0.05$ ).

that may be incorrectly interpreted as a true change in the amount of sugar present in the fruits. Since the mangoes without Policaju-based coatings (control group) showed a higher mass loss, consequently, higher soluble solids concentration occurred in them. As the TSS values were found to be equal for all four treatments and the control group (data not shown), it can be concluded that higher consumption of the previously cited components occurred in the uncoated mangoes during the ripening.

Usually during the storage, an increase of $\mathrm{pH}$ occurs as a consequence of the fruits' ripening (Antunes et al., 2003). In general, food decomposition processes caused by hydrolysis, oxidation, or fermentation modify almost always the concentration of hydrogen ion in the food (Oliveira et al., 1999). Therefore, $\mathrm{pH}$ is an important parameter in the fruit ripening evaluation. The final organic acid content of the fruit is determined by the net balance of acid synthesis, degradation, utilization and compartmentalization (Müller et al., 1996). Both the citric and the malic acids are the major organic acids present in mangoes and their content decreases during the ripening (Medlicott \& Thompson, 1985; Selvaraj et al., 1989; Chen et al., 2009).

Despite the statement above, $\mathrm{pH}$ did not change (no statistically significant difference was observed) during the experimental time (Table 1) in all tested groups of mangoes.

The content decrease of $\mathrm{O}_{2}$ and the consequent increase of $\mathrm{CO}_{2}$ caused by modified atmosphere decrease the loss of acidity during the storage due to the reduction of enzymatic activity related to respiratory metabolism, increasing the $\mathrm{pH}$ of fruits under lower relative humidity (Lima et al., 1996). The fact that the mangoes covered with Policaju-based coatings were stored at $4{ }^{\circ} \mathrm{C}$ suggests that such low temperature induced the diminution in the activity of enzymes of the citric acid cycle (Krebs' cycle). Antunes et al. (2003) found similar results when studying the shelf-life of blackberries at the storage temperature of $2{ }^{\circ} \mathrm{C}$. In this way, in our work, the low storage temperature $\left(4^{\circ} \mathrm{C}\right)$ was the cause of $\mathrm{pH}$ stability.

\section{Conclusions}

Mangoes skins are low-energy surfaces with the surface tension of $(29.04 \pm 0.02) \mathrm{mN} \mathrm{m}^{-1}$ (with polar and dispersive components of $1.47 \mathrm{mN} \mathrm{m}^{-1}$ and $27.57 \mathrm{mN} \mathrm{m}^{-1}$, respectively). Critical surface tension for mangoes is $(22.7 \pm 0.02) \mathrm{mN} \mathrm{m}^{-1}$. Increasing concentrations of Tween 80 resulted in decreasing values of cohesion and adhesion coefficients, thus improving wettability.

Throughout the experiments, mangoes treated with Policaju-based coatings showed lower mass loss in all tested groups, no statistically significant variation was observed for TSS and $\mathrm{pH}$.

Results show that Policaju-based coatings have a positive effect on the shelf-life of mangoes at the storage temperature of $4^{\circ} \mathrm{C}$. From the 15 th day of storage onwards, the concentration of Policaju seems to be determinant for the observed mass loss, which is higher for $0.015 \mathrm{~g} \mathrm{~mL}^{-1}$ Policaju films than for $0.03 \mathrm{~g} \mathrm{~mL}^{-1}$ Policaju films, independently of the presence of Tween 80 .

Acknowledgements. Authors Marthyna P. Souza and Bartolomeu W. S. Souza are recipients of a fellowship from the Coordenação de Aperfeiçoamento de Pessoal de Nivel Superior, Brazil (Capes, Brazil), Miguel A. Cerqueira is recipient of a fellowship from the Fundação para a Cięncia e Tecnologia (FCT, SFRH/BD/23897/2005); financial support from CAPES/Procad/1415/2007 is also gratefully acknowledged.

\section{References}

Antunes, L. E. C., Duarte Filho, J., \& Souza, C. M. (2003). Concervação pós-colheita de frutos de amoreira-preta. Pesquisa Agropecuária Brasileira, 38, 413-419. DOI: 10.1590/S0100$204 X 2003000300011$.

Assis, O. B. G., \& Leoni, A. M. (2003). Filmes comestíveis de quitosana. Revista Biotecnologia, Cięncia e Desenvolvimento, 30, 33-38.

Brunini, M. A., Durigan, J. F., \& Oliveira, A. L. (2002). Avaliação das alterações em polpa de manga 'Tommy-Atkins' congeladas. Revista Brasileira de Fruticultura, 24, 651-653. DOI: 10.1590/S0100-29452002000300019.

Busscher, H. J., van Pelt, A. W. J., de Boer, P., de Jong, H. P., \& Arends, J. (1984). The effect of surface roughening of polymers on measured contact angles of liquids. Colloids and Surfaces, 9, 319-331. DOI: 10.1016/0166-6622(84)80175-4.

Carneiro-da-Cunha, M. G., Cerqueira, M. A., Souza, B. W. S., Souza, M. P., Teixeira, J. A., \& Vicente, A. A. (2009). Physical properties of edible coatings and films made with a polysaccharide from Anacardium occidentale L. Journal of Food Engineering, 95, 379-385. DOI: 10.1016/j.jfoodeng.2009.05.020. 
Casariego, A., Souza, B. W. S., Vicente, A. A., Teixeira, J. A., Cruz, L., \& Díaz, R. (2008). Chitosan coating surface properties as affected by plasticizer, surfactant and polymer concentrations in relation to the surface properties of tomato and carrot. Food Hydrocolloids, 22, 1452-1459. DOI: 10.1016/j.foodhyd.2007.09.010.

Chen, F. X., Liu, X. H., \& Chen, L. S. (2009). Developmental changes in pulp organic acid concentration and activities of acid-metabolising enzymes during the fruit development of two loquat (Eriobotrya japonica Lindl.) cultivars differing in fruit acidity. Food Chemistry, 114, 657-664. DOI: 10.1016/j.foodchem.2008.10.003.

Chien, P., Sheu, F., \& Yang, F. (2007). Effects of edible chitosan coating on quality and shelf life of sliced mango fruit. Journal of Food Engineering, 78, 225-229. DOI: 10.1016/j.jfoodeng.2005.09.022.

Dang, K. T. H., Singh, Z., \& Swinny, E. E. (2008). Edible coatings influence fruit ripening, quality, and aroma biosynthesis in mango fruit. Journal of Agricultural and Food Chemistry, 56, 1361-1370. DOI: $10.1021 /$ jf072208a.

Dann, J. R. (1970). Forces involved in the adhesive process 1. Critical surface tensions of polymeric solids as determined with polar liquids. Journal of Colloid and Interface Science, 32, 302-319. DOI: 10.1016/0021-9797(70)90054-8.

Durango, A. M., Soares, N. F. F., \& Andrade, N. J. (2006). Microbiological evaluation of an edible antimicrobial coating on minimally processed carrots. Food Control, 17, 336-341. DOI: $10.1016 /$ j.foodcont.2004.10.024.

Gomez-Lim, M. A. (1997). Postharvest physiology. In R. E. Litz (Ed.), The Mango: Botany, production and uses (pp. 425446). New York, NY, USA: CAB International.

Jiang, Y., Li, J., \& Jiang, W. (2005). Effects of chitosan coating on shelf life of cold-stored litchi fruit at ambient temperature. LWT - Food Science and Technology, 38, 757-761. DOI: $10.1016 /$ j.l.w.t.2004.09.004.

Kwok, D. Y., \& Neumann, A. W. (1999). Contact angle measurement and contact angle interpretation. Advances in Colloid and Interface Science, 81, 167-249. DOI: 10.1016/S0001-8686(98)00087-6.

Lima, C. O., Scalon, S. P. Q., \& Santos, J. E. S. (1996). Qualidade de mangas (Mangifera indica) cv. 'Haden' embaladas com filme de PVC durante o armazenamento. Revista Brasileira de Fruticultura, 18, 55-63.

Lin, D., \& Zhao, Y. (2007). Innovations in the development and application of edible coatings for fresh and minimally processed fruits and vegetables. Comprehensive Reviews in Food Science and Food Safety, 6, 59-75. DOI: 10.1111/j.15414337.2007.00018x.

Medlicott, A. P., \& Thompson, A. K. (1985). Analysis of sugars and organic acids in ripening mango fruits (Mangifera indica L. var. Keitt) by high performance liquid chromatography. Journal of the Science of Food and Agriculture, 36, 561-566. DOI: $10.1002 /$ jsfa.2740360707.

Maftoonazad, N., \& Ramaswamy, H. S. (2005). Postharvest shelf-life extension of avocados using methyl cellulose-based coating. LWT - Food Science and Technology, 38, 617-624. DOI: $10.1016 /$ j.lwt.2004.08.007.

Menestrina, J. M., Iacomini, M., Jones, C., \& Gorin, P. A. J. (1998). Similarity of monosaccharide, oligosaccharide and polysaccharide structure in gum of Anacardium occidentale L. Phytochemistry, 47, 714-721. DOI: 10.1016/S00319422(97)00666-3.

Mitra, S. K, \& Baldwin, E. A. (1997). Mango. In S. K. Mitra (Ed.), Postharvest physiology and storage of tropical and subtropical fruit (pp. 85-122). New York, NY, USA: CAB International.

Monteiro, F. M. F., Silva, G. M. M., Silva, J. B. R., Porto, C. S., Carvalho, L. B., Jr., Lima Filho, J. L., Carneiro-
Leão, A. M. A., Carneiro-da-Cunha, M. G., \& Porto, A. L. F. (2007). Immobilization of trypsin on polysaccharide film from Anacardium occidentale L. and its application as cutaneous dressing. Process Biochemistry, 42, 884-888. DOI: 10.1016/j.procbio.2007.01.006.

Müller, M. L., Irkens-Kiesecker, U., Rubinstein, B., \& Taiz, L. (1996). One the mechanism of hyperacidification in lemon. The Journal of Biological Chemistry, 271, 1916-1924. DOI: 10.1074/jbc.271.4.1916.

Olivas, G. I., \& Barbosa-Cánovas, G. V. (2005). Edible coatings for fresh-cut fruits. Critical Reviews in Food Science and Nutrition, 45, 657-670. DOI: 10.1080/10408690490911837.

Oliveira, M. E. B., Bastos, M. S. R., Feitosa, T., Branco, M. A. A .C., \& Silva, M. G. G. (1999). Avaliação de parâmetros de qualidade físico-químicos de polpas congeladas de acerola, cajá e caju. Cięncia e Tecnologia de Alimentos, 19, 326-332. DOI: $10.1590 /$ S0101-20611999000300006.

Oms-Oliu, G., Soliva-Fortuny, R., \& Martín-Belloso, O. (2008). Edible coatings with antibrowning agents to maintain sensory quality and antioxidant properties of fresh-cut pears. Postharvest Biology and Technology, 50, 87-94. DOI: 10. 1016/j.postharvbio.2008.03.005.

Paula, R. C. M., \& Rodrigues, J. F. (1995). Composition and rheological properties of cashew tree gum, the exudate polysaccharide from Anacardium occidentale L. Carbohydrate Polymers, 26, 177-181. DOI: 10.1016/01448617(95)00006-S.

Ribeiro, C., Vicente, A. A., Teixeira, J. A., \& Miranda, C. (2007). Optimization of edible coating composition to retard strawberry fruit senescence. Postharvest Biology and Technology, 44, 63-70. DOI: 10.1016/j.postharvbio.2006.11.015.

Rojas-Graü, M. A., Raybaudi-Massilia, R. M., Soliva-Fortuny, R. C., Avena-Bustillos, R. J., McHugh, T. H., \& MartínBelloso, O. (2007). Apple puree-alginate edible coating as carrier of antimicrobial agents to prolong shelf-life of freshcut apples. Postharvest Biology and Technology, 45, 254-264. DOI: $10.1016 /$ j.postharvbio.2007.01.017.

Rulon, J., \& Robert, H. (1993). Wetting of low-energy surfaces. In J. C. Berg (Ed.), Wettability (Surfactant Science, Vol. 49). New York, NY, USA: Marcel Dekker.

Schirato, G. V, Monteiro, F. M. F., Silva, F. O., Lima-Filho, J. L., Carneiro-Leão, A. M. A., \& Porto, A. L. F. (2006). O polissacarídeo do Anacardium occidentale L. na fase inflamatória do processo cicatricial de lesões cutâneas. Ciencia Rural, 36, 149-154. DOI: 10.1590/S0103-84782006000100022.

Selvaraj, Y., Kumar, R., \& Pal, D. K. (1989). Changes in sugars, organic acids, amino acids, lipid constituents and aroma characteristics of ripening mango (Mangifera indica L.) fruit. Journal of Food Science and Technology, 26, 308-313.

Shivashankara, K. S., Isobe, S., Al-Haq, M. I., Takenaka, M., \& Shiina, T. (2004). Fruit antioxidant activity, ascorbic acid, total phenol, quercetin, and carotene of Irwin mango fruits stored at low temperature after high electric field pretreatment. Journal of Agricultural and Food Chemistry, 52, 12811286. DOI: $10.1021 /$ jf0302431.

Song, B., \& Springer, J. (1996). Determination of interfacial tension from the profile of a pendant drop using computer-aided image processing: 1. Theoretical. Journal of Colloid and Interface Science, 184, 64-76. DOI: 10.1006/jcis.1996.0597.

Sothornvit, R., \& Rodsamran, P. (2008). Effect of a mango film on quality of whole and minimally processed mangoes. Postharvest Biology and Technology, 47, 407-415. DOI: 10.1016/j.postharvbio.2007.08.005.

Zisman, W. A. (1964). Contact angle, wettability and adhesion. In F. M. Fowkes (Ed.), Advances in chemistry (Vol. 43, pp. 1-51). Washington, DC, USA: American Chemical Society. 